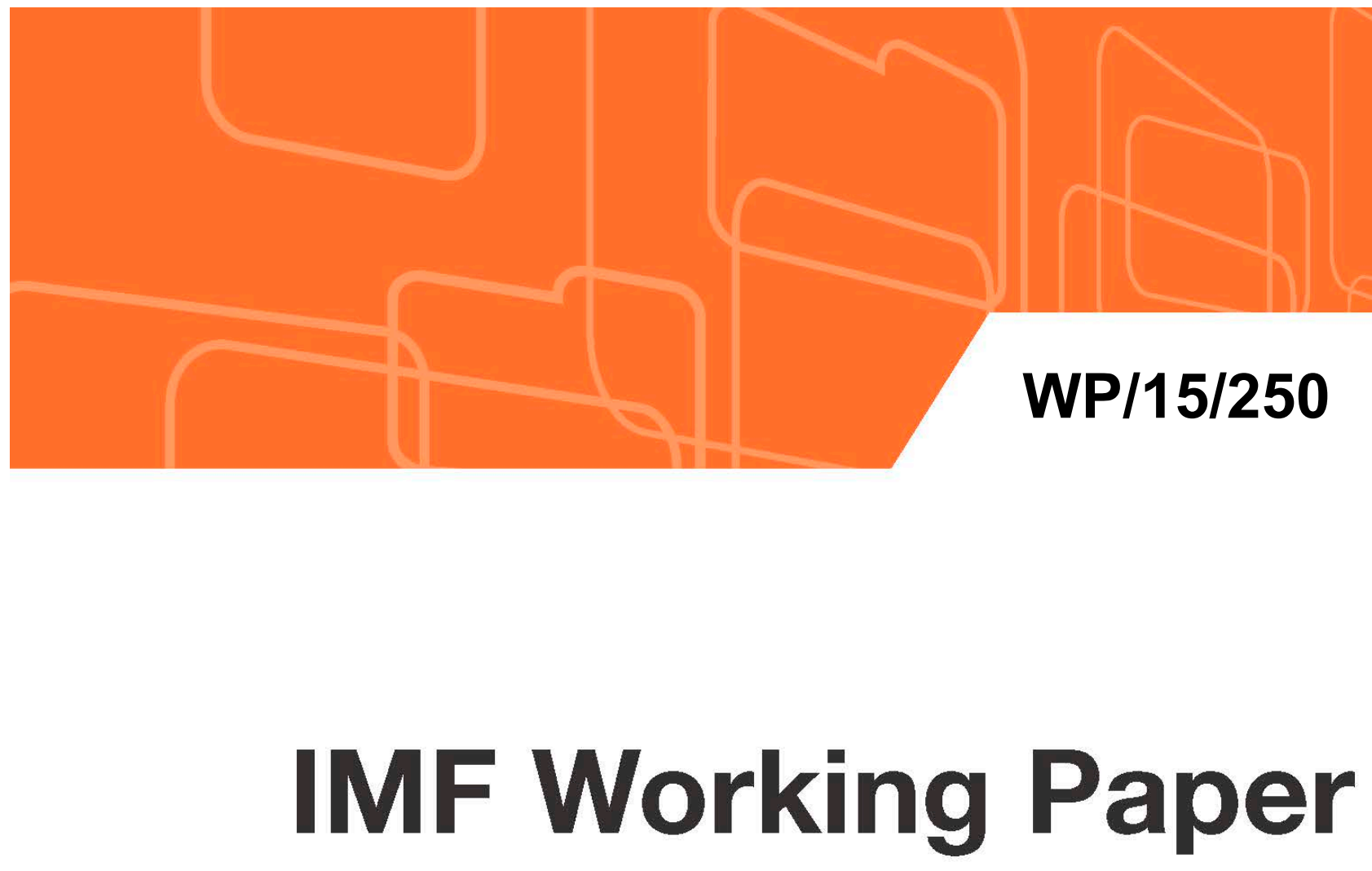

\title{
The Unequal Benefits of Fuel Subsidies Revisited: Evidence for Developing Countries
}

by David Coady, Valentina Flamini, and Louis Sears

IMF Working Papers describe research in progress by the author(s) and are published to elicit comments and to encourage debate. The views expressed in IMF Working Papers are those of the author(s) and do not necessarily represent the views of the IMF, its Executive Board, or IMF management.
I $N$
$N T E R$
N A
A T $\|$ O N A L
M O N E T A R Y
$F \cup \mathbb{N}$ 


\title{
IMF Working Paper
}

Fiscal Affairs Department

\section{The Unequal Benefits of Fuel Subsidies Revisited: Evidence for Developing Countries ${ }^{1}$ Prepared by David Coady, Valentina Flamini, and Louis Sears}

November 2015

\begin{abstract}
IMF Working Papers describe research in progress by the author(s) and are published to elicit comments and to encourage debate. The views expressed in IMF Working Papers are those of the author(s) and do not necessarily represent the views of the IMF, its Executive Board, or IMF management.
\end{abstract}

\begin{abstract}
Understanding who benefits from fuel price subsidies and the welfare impact of increasing fuel prices is key to designing, and gaining public support for, subsidy reform. This paper updates evidence for developing countries on the magnitude of the welfare impact of subsidy reform and its distribution across income groups, incorporating more recent studies and expanding the number of countries. These studies confirm that a very large share of benefits from price subsidies goes to high-income households, further reinforcing existing income inequalities. The results can also help to approximate the welfare impact of subsidy reform for countries where the data necessary for such an analysis is not available.
\end{abstract}

JEL Classification Numbers: H21, H22, H23

Keywords: Fuel subsidy reform, welfare impact, distribution, developing countries

Authors' E-Mail Addresses: dcoady@imf.org; vflamini@imf.org

\footnotetext{
${ }^{1}$ We are grateful for comments received from various colleagues at the Fiscal Affairs Department at the IMF and to Adam Boyd for excellent administrative assistance. This paper will also be published as Chapter 14 in Inequality and Fiscal Policy, edited by Benedict Clements, Ruud de Mooij, Sanjeev Gupta, and Michael Keen (International Monetary Fund, 2015).
} 


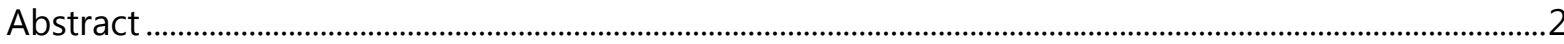

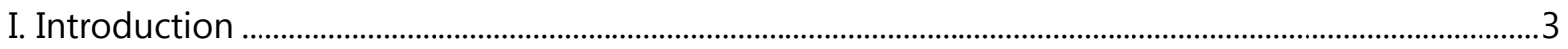

II. Trends in International Oil Prices and Domestic Pass-Through ..........................................................

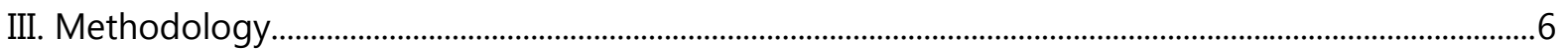

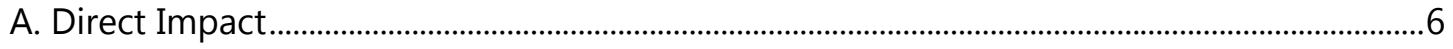

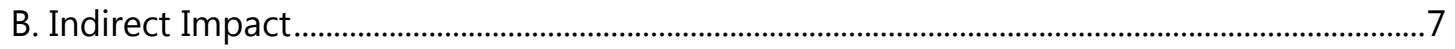

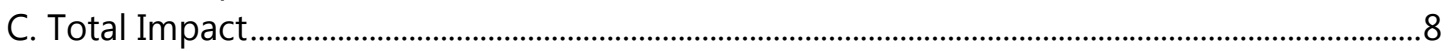

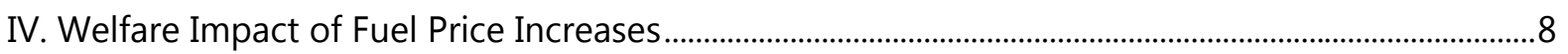

A. Magnitude and Composition of Welfare Impact .........................................................................

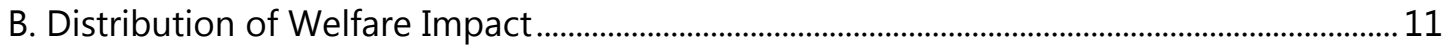

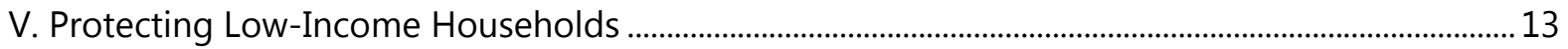

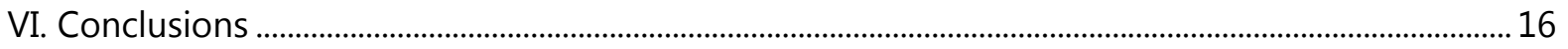

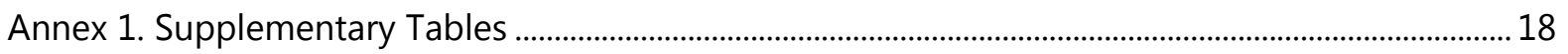

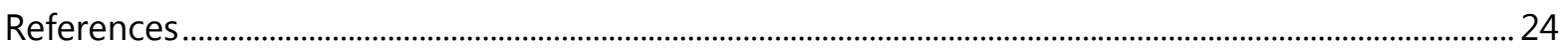

Table

1. Diesel Price Pass-Through and Net Taxes in Developing Countries, 2004-12 ....................................5

Figures

1. International Oil Prices and Domestic Pass-Through, 2000-14 .............................................................

2. Direct and Indirect Welfare Impacts of Fuel Price Increases...................................................................

3. Prices, Consumption, and Total Welfare Impact for Diesel and Gasoline ............................................9

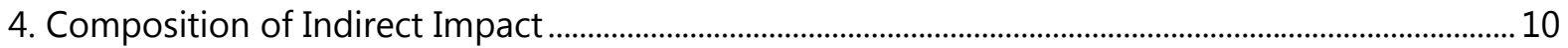

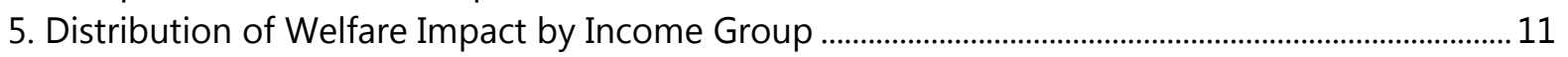

6. Distribution of Subsidy Benefits by Income Group .............................................................................. 12

7. Cost of Providing $\$ 1$ to the Poorest 40 percent of Households via Fuel Subsidies ....................... 13

Box

1. Reforming Fuel Subsidies: Lessons from International Experience ....................................................... 14

Annex Tables

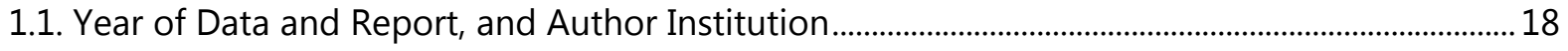

1.2. Adjustment Factors by Country Study and Fuel Product .................................................................. 19

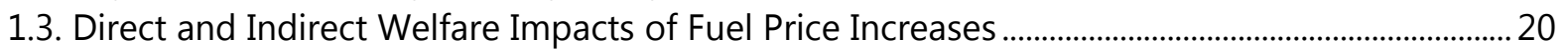

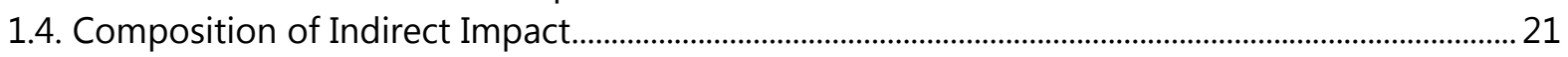

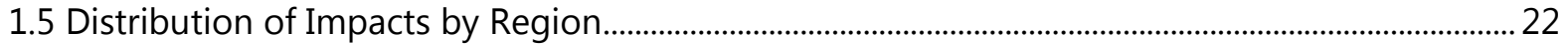

1.6 Distribution of Subsidy Benefits by Consumption Group ......................................................................2 


\section{INTRODUCTION}

The negative economic and environmental effects of fuel subsidies are widely recognized. But these subsidies are also undesirable from an equity perspective since they exacerbate income inequalities and are not a cost-effective approach to protecting the poor. Their adverse impact on inequality arises through two channels. First, the benefits of fuel subsidies are distributed in proportion to household energy consumption, and the consumption baskets of higher-income households are typically more energy intensive than those of lower-income households. Second, public expenditures on energy subsidies can crowd out more redistributive public spending or require financing through regressive taxation. Yet governments in developing countries remain reluctant to remove subsidies because of the adverse impact of higher fuel prices on household real incomes, in particular of lower-income households who are least able to absorb the cost of higher fuel prices. Information on the magnitude of the income loss from fuel price increases, and its distribution across income groups, is therefore a key input into designing more costeffective policies to protect the most vulnerable social groups and gaining political and public support for reducing subsidies.

This paper updates evidence from country studies that estimate the welfare impact of fuel price increases on households. It does so by extending the cross-country evidence reviewed by Arze del Granado, Coady, and Gillingham (2012) to include more recent studies for a larger number of countries. Arze del Granado, Coady, and Gillingham (2012) reviewed estimates of welfare impacts for 20 countries from Africa, Asia, the Middle East, and Latin America, undertaken between 2005 and 2009. This paper extends the survey to 32 countries up to 2014. In some instances, more recent studies for countries already covered became available so the number of new studies reviewed is larger than the number of countries added to the sample. The analysis confirms that a very large share of benefits from fuel price subsidies goes to high-income households, further reinforcing existing income inequalities. These results can also be used to approximate the welfare impact of fuel subsidies in future country studies for which the data necessary for the analysis are not available.

The paper is structured as follows. It first presents evidence on the fiscal importance of energy subsidies before describing recent trends in international oil prices, the extent to which these changes have been passed through to domestic fuel prices in various regions, and the resulting fiscal implications. It then briefly outlines the methodology used to estimate the welfare impact of fuel price increases aimed at reducing the fiscal cost of fuel subsidies. The empirical results of the survey are presented by looking at the magnitude, composition, and distribution of the welfare impact of fuel subsidy reform. Finally, it provides an overview of issues that need to be addressed when designing an energy subsidy reform strategy, with an emphasis on safety net measures to protect the poor. 


\section{Trends in International Oil Prices and Domestic Pass-Through}

Fuel subsidies arise in many developing countries because domestic consumer prices for fuel products are directly controlled by governments and are only adjusted on an ad hoc basis in an attempt to protect domestic consumers from high and volatile oil prices. International price increases are often perceived as temporary and therefore not passed onto domestic consumers. But if international price increases are sustained, the domestic price increases required to eliminate subsidies quickly become more politically challenging, resulting in policy inertia and escalating subsidies.

After the mid-2000s, international oil prices started to increase steadily before increasing more sharply during 2007 and the first half of 2008 (Figure 1). Across all developing regions, many countries failed to pass these increases on to domestic consumers. For instance, more than half of developing countries passed on less than two-thirds of the increase in international diesel prices to domestic consumers during this period (Table 1). The pass-through was especially low in the Middle East and North Africa region, where half of the countries passed through less than 13 percent of international price increases. Incomplete pass-through led to a substantial increase in subsidies in many countries, particularly in countries in the Middle East and North Africa as well as in developing Asia. The resulting fiscal cost was substantial, with the combined cost for diesel, gasoline, and kerosene exceeding 3 percent of GDP on an annualized basis in more than half of developing countries. The total fiscal cost would be even higher if subsidies to other energy products, such as liquefied petroleum gas (LPG) and electricity, were included (Clements and others 2013).

Figure 1. International Oil Prices and Domestic Pass-Through, 2000-14 (Index, January $2000=100$ )

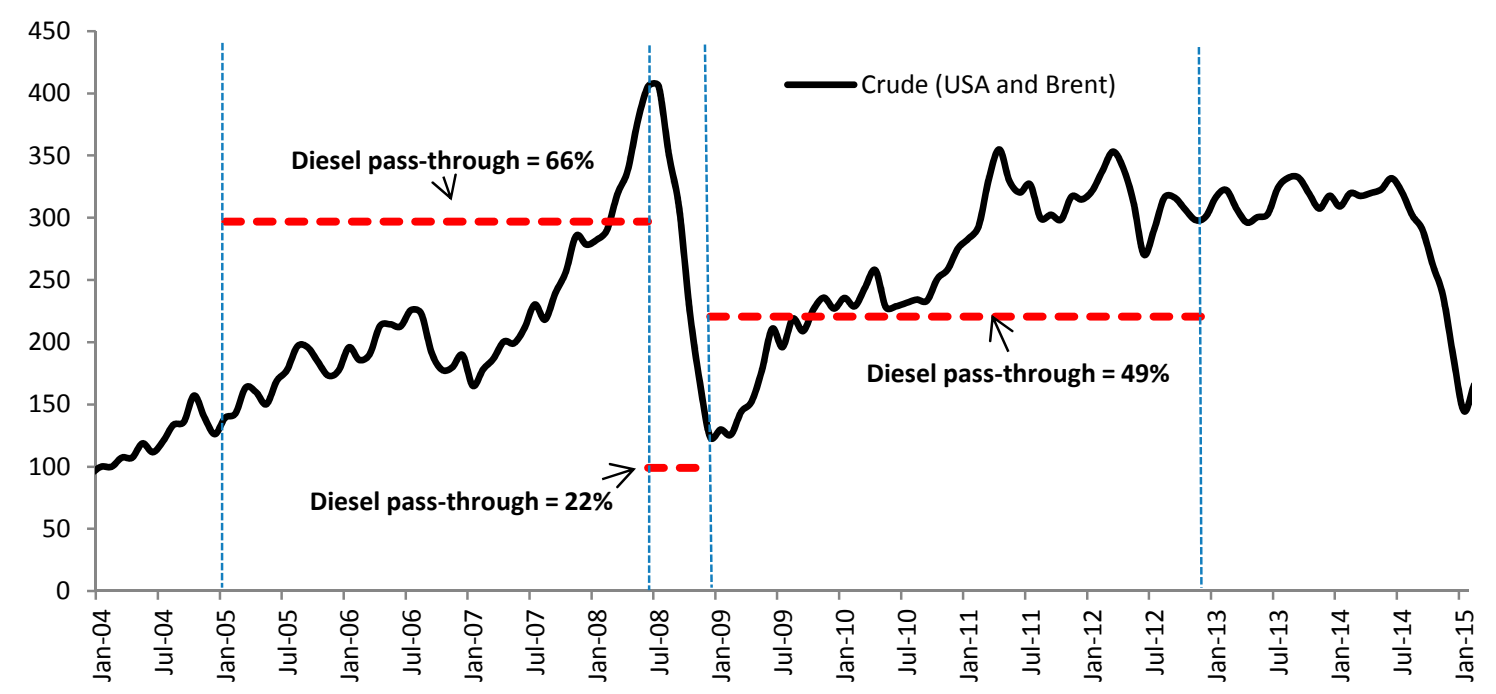

Sources: IMF, World Economic Outlook, April 2015; U.S. Energy Information Administration; IMF staff estimates.

Note: Pass-through is defined as the change in domestic prices divided by the change in international prices in U.S. dollars. 
Table 1. Diesel Price Pass-Through and Net Taxes in Developing Countries, 2004-12

\begin{tabular}{|c|c|c|c|c|c|}
\hline & & $\begin{array}{c}\text { End- } \\
2004- \\
\text { Mid-2008 }\end{array}$ & $\begin{array}{c}\text { Mid-2008- } \\
\text { End-2008 }\end{array}$ & $\begin{array}{c}\text { End- } \\
2008- \\
\text { End-2012 }\end{array}$ & $\begin{array}{c}\text { End- } \\
2013- \\
\text { End-2014 }\end{array}$ \\
\hline \multicolumn{6}{|c|}{ Median pass-through (Percent) } \\
\hline Developing Economies $\{118\}$ & & 66 & 22 & 49 & 11 \\
\hline Developing Asia $\{28\}$ & & 65 & 12 & 54 & 40 \\
\hline Latin America and the Caribbean $\{32\}$ & & 51 & 28 & 83 & 12 \\
\hline Middle East and North Africa $\{19\}$ & & 13 & 1 & 10 & 0 \\
\hline Sub-Saharan Africa $\{39\}$ & & 85 & 38 & 35 & 0 \\
\hline \multicolumn{6}{|c|}{ Median fiscal cost (Percent of GDP) } \\
\hline Developing Economies $\{118\}$ & & 1.92 & -3.14 & 1.74 & -0.88 \\
\hline Developing Asia $\{28\}$ & & 1.43 & -4.68 & 2.24 & -0.89 \\
\hline Latin America and the Caribbean $\{32\}$ & & 2.50 & -2.98 & 1.27 & -0.80 \\
\hline Middle East and North Africa $\{19\}$ & & 1.93 & -3.44 & 3.20 & -1.89 \\
\hline Sub-Saharan Africa $\{39\}$ & & 2.15 & -3.42 & 1.50 & -0.92 \\
\hline \multicolumn{6}{|c|}{ Median net-tax (US\$/liter) } \\
\hline & End-2004 & Mid-2008 & End-2008 & End-2012 & End-2014 \\
\hline Developing Economies $\{118\}$ & 0.10 & -0.08 & 0.33 & 0.22 & 0.37 \\
\hline Developing Asia $\{28\}$ & -0.11 & -0.37 & 0.17 & 0.05 & 0.16 \\
\hline Latin America and the Caribbean $\{32\}$ & 0.09 & -0.08 & 0.29 & 0.22 & 0.29 \\
\hline Middle East and North Africa $\{19\}$ & -0.14 & -0.78 & -0.12 & -0.36 & 0.07 \\
\hline Sub-Saharan Africa $\{39\}$ & 0.27 & 0.14 & 0.54 & 0.32 & 0.47 \\
\hline
\end{tabular}

Sources: Deutsche Gesellschaft für Internationale Zusammenarbeit (GIZ); International Energy Agency; U.S. Energy Information Agency; IMF staff estimates.

Note: Pass-through is defined as the change in domestic prices divided by the change in international prices in U.S. dollars. Fiscal cost refers to the increase in fuel subsidies or decrease in tax revenues for gasoline, diesel, and kerosene, based on changes in end-of-period prices and annualized cost. Net taxes per liter are calculated as domestic retail prices minus import and distribution costs; a negative value indicates prevalence of subsidies. Numbers in brackets refer to the size of the sample of countries in each group. Sample size for end-2013-end-2014 is lower than previous periods, totaling 102 developing countries rather than 118.

After peaking in mid-2008, international prices plummeted during the following six months. As prices began to fall, many countries passed through very little of the decline to consumers in an attempt to recoup past revenue losses. During this period, pass-through fell below 20 percent in more than half of the developing countries, and was below 1 percent in most of the Middle East 
and North Africa region. ${ }^{2}$ As a result, fuel tax levels increased and subsidies decreased. For instance, by end-2008 the median net tax per liter in sub-Saharan Africa was around four times higher than at midyear, unit subsidies in Middle East and North Africa countries shrank by 85 percent, while median net taxes in developing Asia and Latin America and the Caribbean turned positive (Table 1). However, the relief was short-lived because international oil prices rebounded sharply beginning in early 2009—by April 2011 international prices had almost reached the peak levels seen in mid-2008. Again, taxes fell and subsidies increased during the next few years, and the fiscal costs associated with controlled prices escalated, wiping out much of the fiscal gain accrued during the second half of 2008.

The decline in international prices in late 2014-early 2015 has presented countries with another opportunity to adopt a permanent solution to the burden of energy subsidies. However, transforming this temporary respite into a permanent solution will require advance planning and foresight on the part of policymakers. In this respect, knowledge of the magnitude and distribution of the impact of fuel price increases on real household incomes is crucial to designing measures to mitigate the impact on the poor, which in turn is important for making reforms politically feasible and durable.

\section{Methodology}

The impact of increasing domestic fuel prices on the welfare of households arises through two channels. First, households face the direct impact of higher prices for fuels consumed for cooking, heating, lighting, and personal transport. Second, an indirect impact is felt through higher prices for other goods and services consumed by households as higher fuel costs are reflected in increased production costs and consumer prices. The magnitude of these impacts depends on the importance of cooking, lighting, heating, and personal transport costs in total household consumption, as well as on the fuel intensity of other goods and services consumed by households. The distribution of the impacts across different income groups will depend on the relative importance of these factors across income groups. For example, if the consumption baskets of higher-income groups are relatively more fuel intensive than those of lower-income groups, then the impact on higher-income groups will be relatively large.

\section{A. Direct Impact}

Evaluating the direct impact requires survey data on household expenditures that include detailed information on fuel consumption. These data can be used to calculate the budget share for each fuel product for each household, that is, total household expenditure on each fuel

\footnotetext{
2 However, over recent year, some countries have taken steps to increase energy prices: Jordan eliminated fuel subsidies in 2012 and increased electricity tariffs over the past few years; Sudan increased fuel prices in 2012 and 2013; and Yemen did the same in 2014. These are steps in the right direction, but a strategy to provide a permanent solution to energy subsidies still needs to be developed.
} 
product divided by total household consumption. All of the studies in this review use such data to calculate the direct impact of fuel price increases on households. The budget share for a given fuel provides an estimate of the welfare impact of a doubling of the fuel price absent any demand response. For example, if the budget share for gasoline is 0.05 (the household allocates 5 percent of its total consumption budget to gasoline), a doubling of the price of gasoline will result in a decrease in welfare for the household equivalent to a 5 percent decrease in real income. Given the underlying assumption of no demand response, these welfare impacts should be interpreted as short-term impacts or upper bounds on longer-term impacts.

\section{B. Indirect Impact}

Most of the country studies evaluate the indirect impact of higher fuel prices by estimating the impact on the prices of other goods and services, which requires a price-shifting model. The model used in these studies is based on that presented in Coady and Newhouse (2006), which assumes that increases in fuel production costs are fully passed forward onto the domestic prices of goods and services. Estimating these price increases requires information on the production structure of the economy; for example, an input-output table describing the share of different inputs in the production cost structure. While recent household survey data are often available, this is not the case for input-output tables, which are often more outdated. A key implication is that the fuel cost shares across sectors will tend to underestimate (overestimate) current shares if prices have increased (decreased) in the meantime. Therefore, the impact of fuel price increases on economy-wide prices, and the resulting welfare losses, will be underestimated (overestimated).

The approach used to estimate the indirect impact on the prices of other goods and services implicitly assumes that goods are nontraded, that domestic production technologies exhibit constant returns to scale, and that demand is completely price inelastic (Chapter 3 of Newbery and Stern, 1987). The nontraded assumption is arguably less problematic in the present context since much of the indirect impact of fuel price increases comes from the higher cost of domestic transport for distributing goods and services within a country, and this component of all goods and services is inherently nontraded. The full pass-through of higher production costs to domestic consumer prices is also facilitated by the fact that the prices of all imported goods are also likely to be similarly affected by higher international fuel prices. However, the assumption of demand inelasticity means that estimates should again be interpreted as short-term impacts or upper bounds on long-term impacts. Once the impact of higher domestic fuel prices on the prices of other goods and services is estimated, these estimates are multiplied by the household budget share for each of these consumption categories (taken from a household survey) to get the welfare impact of each price change. These welfare impacts are then aggregated to estimate the total indirect welfare impact of fuel price increases for each household. 


\section{Total Impact}

The total impact of fuel price increases is calculated as the sum of the direct and indirect impacts. The distribution of the impact across households in different parts of the income distribution is estimated by calculating the average impact for households in different income groups. Consistent with most studies of poverty and inequality, households are allocated to welfare quintiles based on a measure of consumption per capita or per adult equivalent (that is, consumption adjusted for different needs reflecting different household demographic composition). The distribution of the welfare impact from a price increase is classified as progressive (regressive) if the percentage welfare loss increases (decreases) with household consumption. Whether subsidized fuel prices are an effective approach to protecting the welfare of low-income households will depend on the share of the total benefit from low fuel prices that accrues to lower-income households. Effective targeting requires that a high proportion of benefits accrue to lower-income households; if a substantial proportion of benefits leak to higher-income households, it is likely that more cost-effective approaches to social protection are possible.

\section{Welfare Impact OF Fuel Price InCReAses}

As in Arze del Granado, Coady, and Gillingham (2012), this paper reviews country studies that were conducted mainly by staff at the IMF and World Bank following a comparable methodology, and recalculates the welfare impact based on a common price increase of $\$ 0.25$ per liter. The recalculation is done by scaling welfare impacts proportionally to reflect different initial retail price levels across countries. Annex Table 1.1 presents the list of all case studies used in this review, as well as their source data and author institution. The adjustment factors used to convert the original into the common price increase of $\$ 0.25$ per liter are presented in Annex Table 1.2. In many countries, higher fuel prices also lead governments to increase electricity tariffs if electricity uses fuel as an input. Since the most recent country reports reviewed in this paper do not include information on electricity tariff reforms, this paper does not provide additional evidence on the welfare impact and distribution of higher electricity tariffs and only reports results from the original article for ease of reference.

\section{A. Magnitude and Composition of Welfare Impact}

The total (direct plus indirect) impact on households of a $\$ 0.25$ per liter increase in fuel prices is sizable, and the indirect portion accounts for a substantial share of this impact. On average, such an increase in fuel prices results in a 5.5 percent decline in household real incomes, with the impact ranging from 3.5 percent in South and Central America to 7.0 percent in the Middle East (Figure 2). Annex Table 1.3 presents country- and product-specific results.

The welfare impact is higher in the Middle East and Central Asia, where retail fuel prices are comparatively low (Figure 3, panel 1). Because the simulated price increase is the same across regions, differences in the magnitude of its impact can be expected to reflect a volume effect 
due to higher consumption of fuels where retail prices are low. In general, data show an inverse relationship between retail prices of diesel and gasoline and consumption of these products as a share of national income. For instance, in panel 2 of Figure 3, advanced economies and emerging countries in Europe, which have higher average retail prices, tend to display low consumption of diesel and gasoline. In contrast, countries in the Middle East and Central Asia have lower average prices and higher consumption of fuels. This difference is consistent with higher energy prices providing stronger incentives for improving energy efficiency.

Figure 2. Direct and Indirect Welfare Impacts of Fuel Price Increases

(Percent of household total consumption)

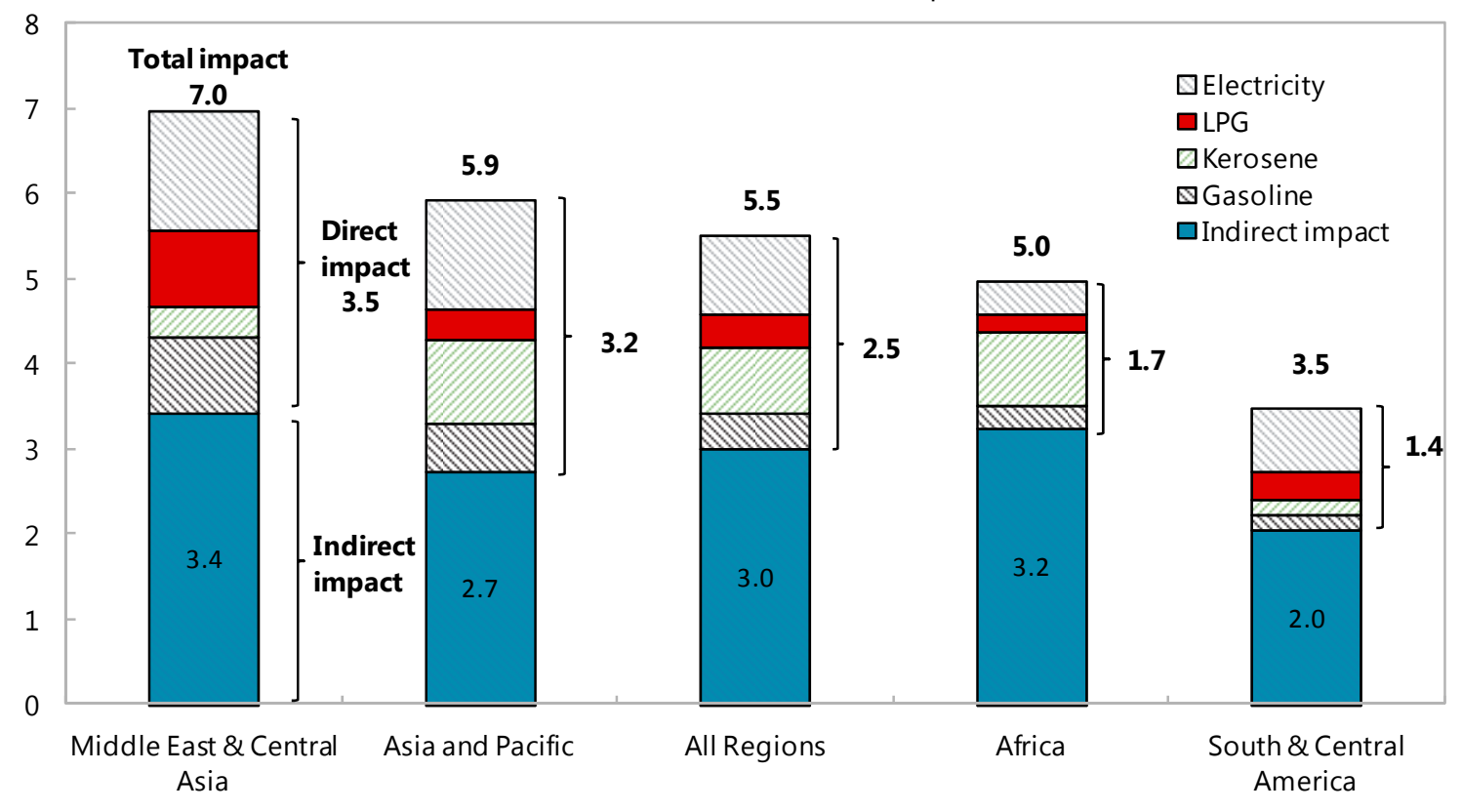

Source: Authors' calculations based on results from reviewed studies.

Note: $L P G=$ liquefied petroleum gas.

Figure 3. Prices, Consumption, and Total Welfare Impact for Diesel and Gasoline
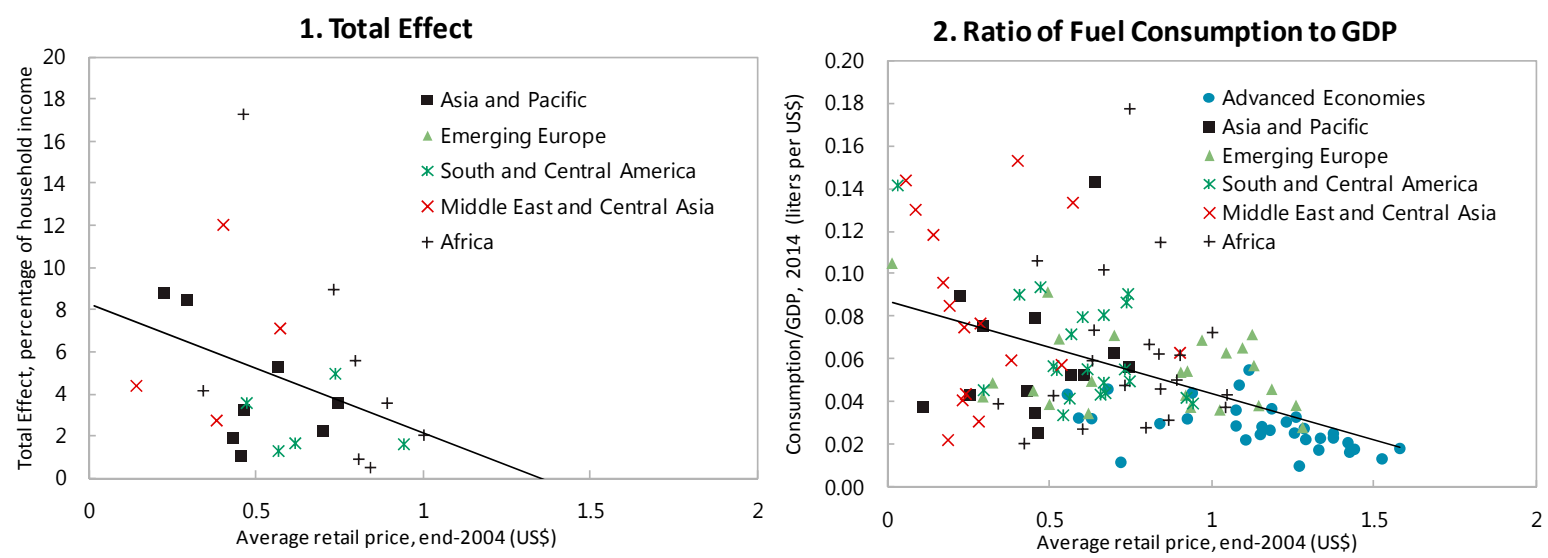

Source: Authors' calculations based on results from reviewed studies. 
Although, on average, the indirect impact accounts for 55 percent of the total impact, its share differs substantially across regions. Whereas the indirect effect is 65 and 60 percent of the total impact in sub-Saharan Africa and South and Central America, respectively, it is less than 50 percent in Asia and Pacific and in the Middle East and Central Asia. However, in all cases, it is a sizable component of the total impact, reflecting the fact that a high proportion of total fuel consumption is for intermediate use. Therefore, it is important for any evaluation of the welfare impact of fuel price changes to incorporate this indirect effect.

The magnitude of the indirect impact on households depends on the fuel intensity of their consumption. Figure 4 presents data on the average budget share for food, transport, and "other" goods and services (excluding direct fuel consumption). It also presents the estimated effect of the simulated fuel price changes on the prices of each of these categories, as well as the aggregate indirect welfare impact across each of these categories. Transport expenditures include household use of privately and publicly provided public transport services (that is public and privately owned buses, taxis, and other forms of public transport). The indirect effect is calculated as a budget-share weighted average of price changes across these consumption categories. On average, the slightly lower budget share for "other" compared with food is offset by the greater fuel intensity of "other" goods and services, as reflected in its higher price effect. As a result, on average, higher prices of "other" goods account for slightly less than 50 percent of the indirect impact on households and higher food prices for about 40 percent. Although transport services absorb, on average, only 4.1 percent of household budgets, the relatively large price effect (reflecting the relatively high energy intensity of these services) means that it accounts for about 12 percent of the indirect impact. Annex Table 1.4 presents a breakdown of the indirect welfare impact by country.

Figure 4. Composition of Indirect Impact

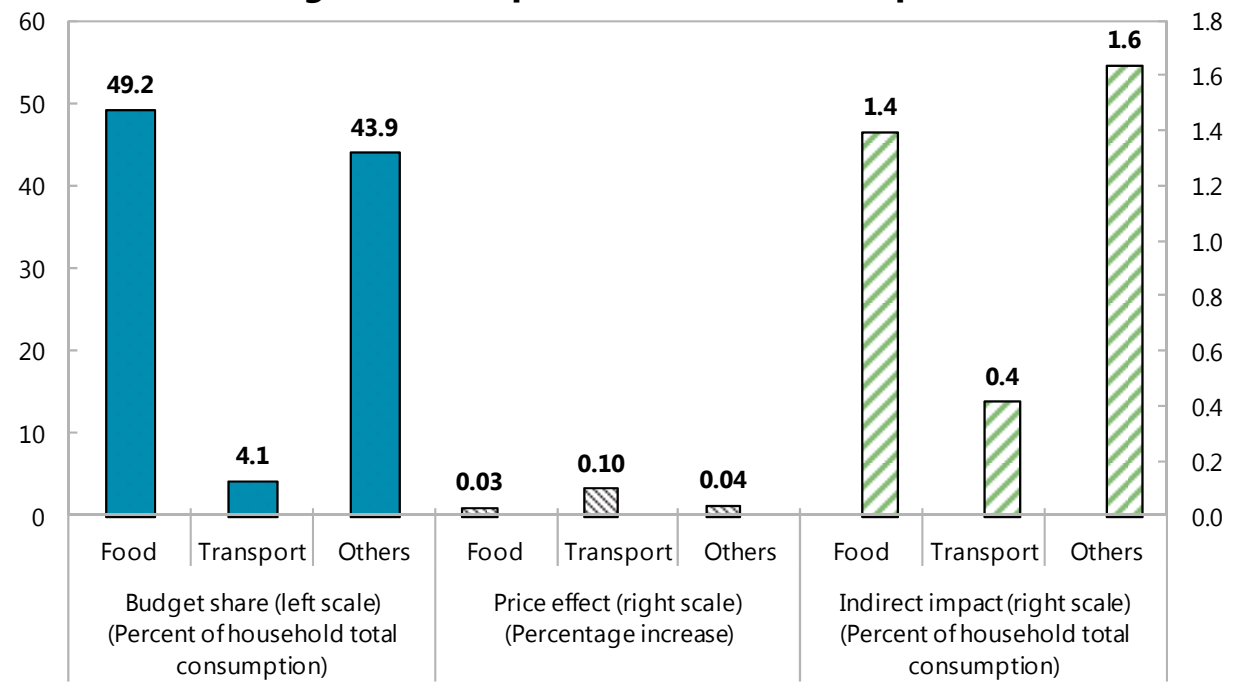

Source: Authors' calculations based on results from reviewed studies.

1/Category "Others" excludes fuel products directly consumed by households for cooking, lighting, and transport. Hence, budget shares do not add to 100, but to 100 minus households' share of direct consumption in fuels. 
The composition of the direct effect also differs across regions. For example, kerosene is relatively important in Africa because of the low level of household access to electricity, and is much less important in the Middle East and in South and Central America because access to electricity is more extensive. However, low-income household access to certain fuels can mean that the estimates in Annex Table 1.3 for each fuel may substantially underestimate the impact on households with access. For example, if only half of households have access to electricity, the impact on electricity users will be double that presented in the table. In practice, this issue is often especially important for electricity and LPG.

\section{B. Distribution of Welfare Impact}

The total, direct, and indirect welfare impacts are approximately distributionally neutral, with the percentage decrease in welfare being very similar across income groups (Figure 5). However, substantial variation across products is hidden for the direct effect. The impacts for gasoline and electricity are strongly progressive, but the kerosene impact is strongly regressive. The distribution of the impact of LPG seems to differ across regions. On average, the simulated impact of the increase in LPG prices is slightly progressive, but is very regressive in the Middle East and Central Asia region. Annex Table 1.5 presents the distribution of the direct and indirect welfare impacts across income groups, disaggregated by region and country.

Figure 5. Distribution of Welfare Impact by Income Group

(Percent of household total consumption)

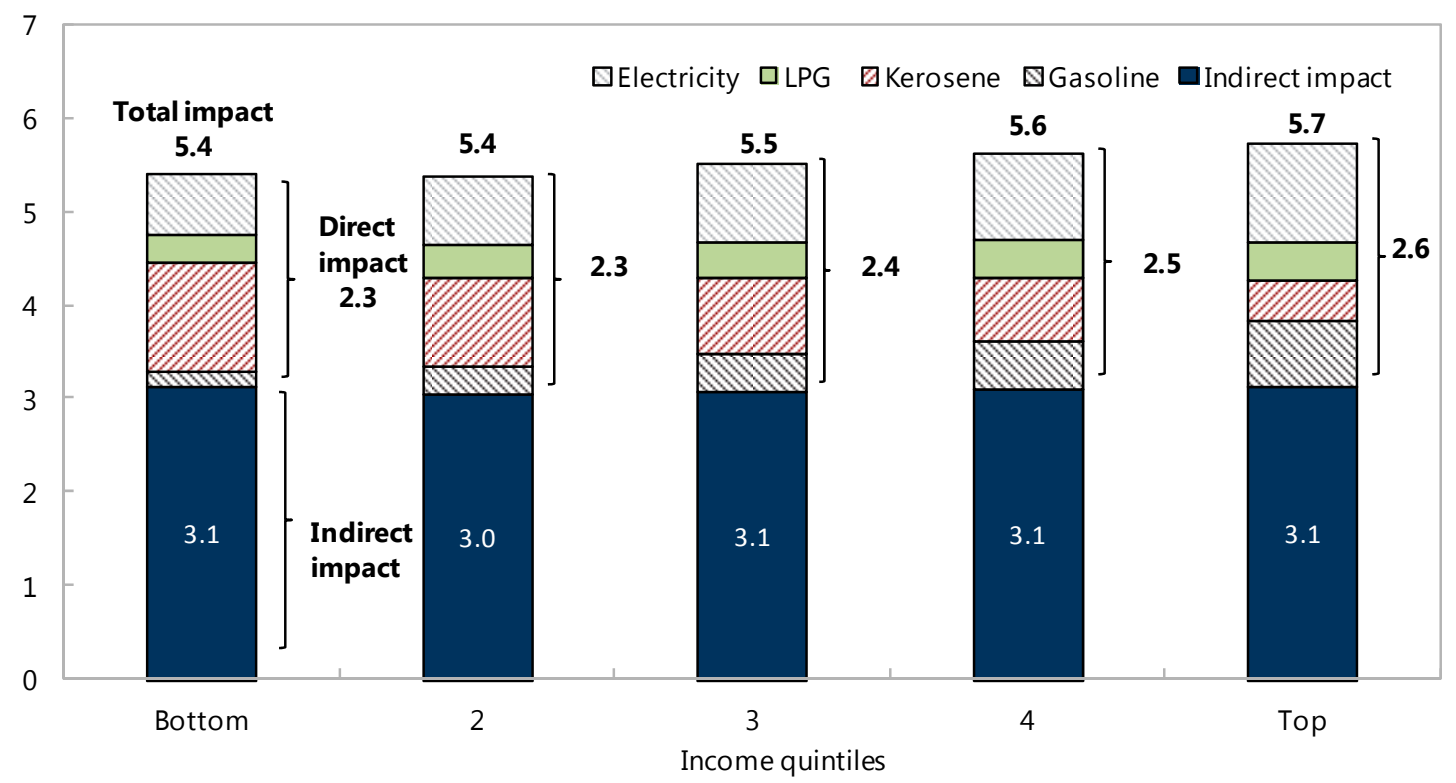

Source: Authors' calculations based on results from reviewed studies.

Note: $L P G=$ liquefied petroleum gas.

Since the distribution of the total impact of fuel price increases is approximately neutral, significantly higher total consumption levels of well-off households mean substantial leakage of benefits to higher-income groups. Therefore, maintaining low fuel prices results in a badly 
targeted subsidy. Figure 6 presents the shares of the total benefits that each income group would receive from subsidized fuel prices, separately for the total, direct, and indirect welfare impact as well as for the direct benefit for gasoline, LPG, and kerosene. On average, the top income quintile receives more than six times more in total subsidies than the bottom quintile. The concentration of subsidy benefits in the hands of the top income groups is even more pronounced for gasoline and LPG, where the top income quintile receives 27 and 12 times that of the bottom quintile, respectively. Although the poorest households receive a much higher share of kerosene subsidies than for other fuel subsidies, there is still substantial leakage of kerosene subsidies to higher-income groups. Annex Table 1.6 presents the shares of the total benefits that each income group would receive from subsidized fuel prices, disaggregated by region.

\section{Figure 6. Distribution of Subsidy Benefits by Income Group}

(Percent of total subsidy benefit)
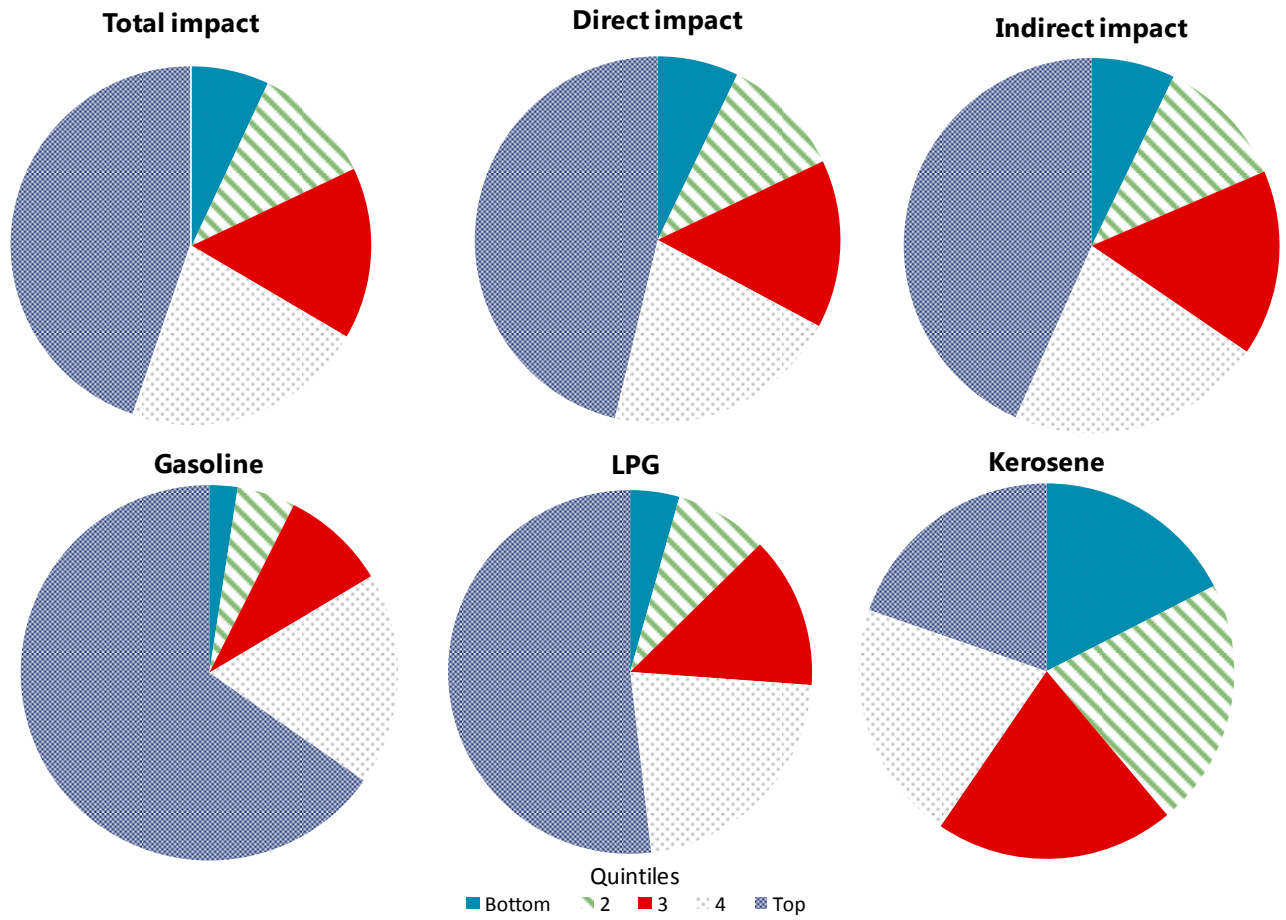

Source: Authors' calculations based on results from reviewed studies.

Note: $L P G=$ liquefied petroleum gas. The indirect impact is the welfare impact of higher prices of goods and services due to an increase in the price of diesel.

The substantial leakage of subsidy benefits to the top income groups means that universal fuel subsidies are an extremely costly approach to protecting the welfare of poor households. For example, if we take the poorest 40 percent of households to be the target "poor" group, the cost to the budget of transferring one dollar to this group via gasoline subsidies is about 14 dollars. This occurs because nearly 93 out of every 100 dollars of gasoline subsidy "leaks" to the top three quintiles. These leakages are higher in Africa and in Asia and Pacific, where poor households' use of gasoline and LPG is comparatively lower than in other regions (Figure 7, Annex Table 1.6). Even for kerosene, this cost-benefit ratio is about 3 dollars. 
Such high leakage of subsidy benefits means that there is likely to be a high return to developing more cost-effective ways of protecting the real incomes of poor households. For example, if 15 out of every 100 dollars allocated to a safety net program is absorbed by administrative costs and 80 percent of the remaining 85 dollars in beneficiary transfers reaches the poor (or 68 percent of the total budget), then the cost-benefit ratio for such a program is 1.5 dollars, which is substantially lower even than for kerosene subsidies. In addition, the extent of protection that can be given to the poor via kerosene subsidies without severely disrupting fuel markets is very limited. Relatively low kerosene prices result in substitution of kerosene for diesel (legally or illegally) and often lead to shortages for rural households and smuggling to neighboring countries with higher prices.

\section{Figure 7. Cost of Providing $\$ 1$ to the Poorest 40 Percent of Households via Fuel Subsidies}

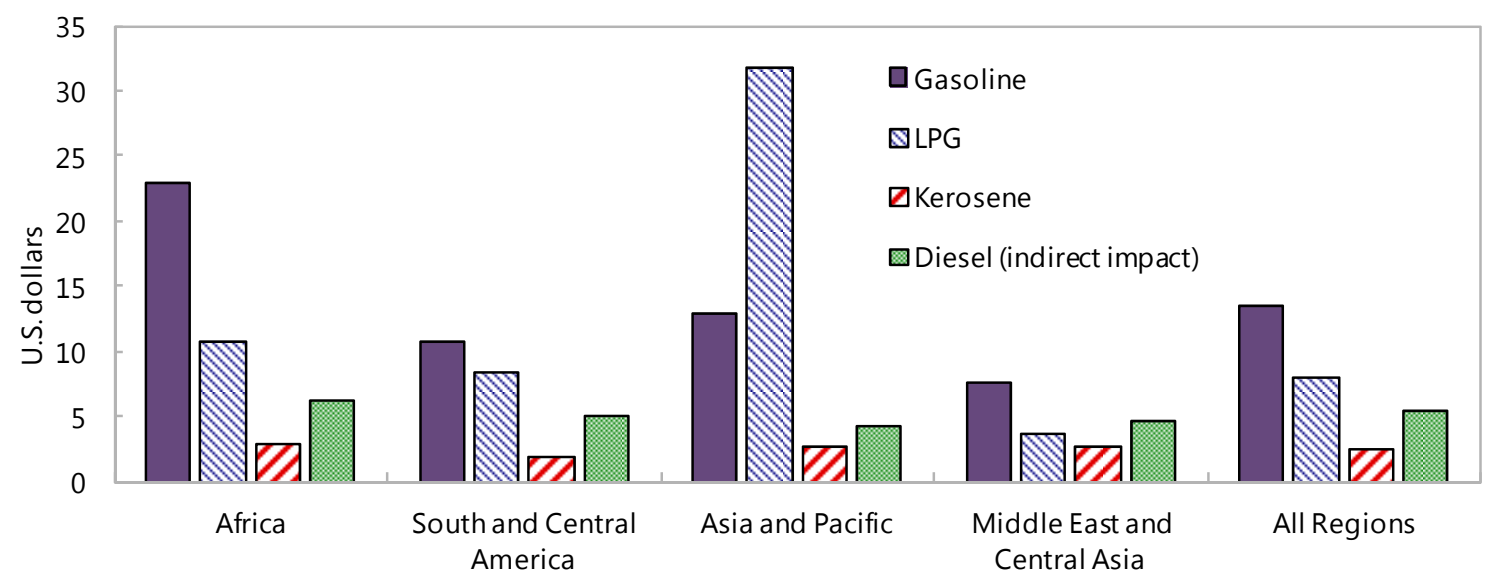

Source: Authors' calculations based on results from reviewed studies.

Note: $L P G=$ liquefied petroleum gas.

For electricity, varying tariff levels according to consumption levels can mitigate the impact of energy price increases on poor households, but this approach to protecting low-income households is often less effective than believed. A large proportion of poor households do not benefit from lower lifeline tariffs because many do not have access to electricity and many with larger family sizes (driven by the number of children) consume at levels above "lifeline thresholds." Moreover, to the extent that lifeline subsidies are financed by higher tariffs for larger electricity consumers, poor households that consume large amounts of electricity could actually be worse off as a result. In practice, therefore, nonlinear electricity pricing (that is, block tariff structures with a lower lifeline tariff) are a very crude way of protecting poor households and can come with important negative side effects.

\section{Protecting Low-Income Households}

Although higher-income groups capture most of the benefits from lower fuel prices, subsidy reform can still result in a sizable reduction in the real incomes of low-income households and thus increased poverty. Therefore, well-targeted measures to mitigate the impact of energy price 
increases on the poor are critical for building public support for subsidy reform. Some approaches in different country contexts are discussed below. Box 1 discusses additional measures that can help promote successful subsidy reform.

\section{Box 1. Reforming Fuel Subsidies: Lessons from International Experience}

International experiences with energy subsidy reform suggest a number of barriers to successful reform, including (1) lack of information regarding the magnitude and shortcomings of subsidies; (2) lack of government credibility and administrative capacity; (3) concerns regarding the adverse impact on the poor; (4) concerns regarding the adverse impact on inflation, international competitiveness, and volatility of domestic energy prices; (5) opposition from specific interest groups benefiting from the status quo; and (6) weak macroeconomic conditions (Clements and others 2013).

Many countries that have successfully reformed energy subsidies have incorporated specific measures into their subsidy reform strategies to overcome these barriers. While there is no single recipe for success, analysis of international reform experiences suggests the following six reform ingredients can help address reform barriers and increase the likelihood that reforms will achieve their objectives, thus helping to avoid policy reversals:

- $\quad$ Develop a comprehensive reform plan-The reform plan should have clear objectives. It should identify specific measures that will achieve these objectives, and include a timeline for implementing and assessing these measures. A comprehensive plan will incorporate many of the measures discussed below. Designing and executing such a reform plan therefore needs careful advance planning.

- $\quad$ Develop an effective communication strategy-An extensive public communication campaign can help generate broad political and public support, help prevent misinformation, and should be undertaken throughout the reform process. Transparency is a key component of a successful communication strategy.

- $\quad$ Appropriately phase and sequence price increases_Phasing in price increases and sequencing them differently across energy products may be desirable. The appropriate phasing and sequencing of price increases will depend on a range of factors, including the magnitude of the price increases required to eliminate subsidies, the economy's fiscal position, the political and social context in which reforms are being undertaken, and the time needed to develop an effective social safety net and communication strategy. However, gradual reform can create additional reform challenges, including lower budgetary savings in the short term, distortion in consumption patterns due to sequencing of reform by energy product, and the risk that opposition may build up over time.

- Improve the efficiency of energy state-owned enterprises (SOEs)_Improving the efficiency of SOEs (refineries, distribution companies, and so on) can reduce the fiscal burden of the energy sector. Energy producers often receive substantial budgetary resources - consisting of both current and capital transfers - to compensate for inefficiencies in production, distribution, and revenue collection. Improvements in efficiency can strengthen the financial position of these enterprises and reduce the need for such transfers. It will also help assure consumers that price increases are not simply being used to protect inefficient and poorly governed producers.

- Implement targeted mitigating measures-Well-targeted measures to mitigate the impact of energy price increases on the poor are critical for building public support for subsidy reforms. The degree to which compensation should be targeted is a strategic decision that involves trade-offs between fiscal savings, capacity to target, and the need to achieve broad acceptance of the reform. Subsidy reform involving SOE restructuring may require temporary, sectorspecific social measures to support employees and enterprises.

- $\quad$ Depoliticize energy pricing-Successful and durable reforms require a depoliticized mechanism for setting energy prices. Establishing an automatic pricing formula for fuel products that links domestic energy prices to international energy prices can help distance the government from the pricing of energy and make it clearer that domestic price changes reflect changes in international prices that are outside the government's control.

Price-smoothing rules can help prevent large price increases. How much smoothing the government chooses to implement will depend on its preference between lower price volatility and higher fiscal volatility. 
Targeted cash transfers or near-cash transfers are typically the preferred approach to compensation. Cash transfers give beneficiaries the flexibility to purchase the level and type of energy that best suits their needs, and at a time and place of their choosing. They also remove the need for governments to be directly involved in the distribution of subsidized energy to households, which is often extremely costly and prone to abuse (Grosh and others 2008). Targeted cash transfers were used to protect poor households in several successful subsidy reform episodes. For example, Armenia successfully introduced a targeted cash transfer program during its electricity reform, which helped poor beneficiaries maintain real consumption in the face of higher electricity bills. Indonesia's nonconditional cash transfer program, which covered 35 percent of the population, was an important component of its successful strategy in overcoming social and political opposition to fuel subsidy reforms. Its experience also suggests that such programs need good preparation and monitoring to effectively assist the poor.

Conditional cash transfer programs that link eligibility for benefits to household investments in the education and health status of family members can both protect poor households from poverty and enhance their human capital base to break the intergenerational transmission of poverty. The expansion of these programs throughout emerging and low-income economies has greatly increased the capacity of these economies to protect poor households from price and other shocks while simultaneously addressing the root causes of persistent poverty (Fiszbein and others 2009; Garcia and Moore 2012; Monchuk 2014).

If cash transfers are not feasible, as is the case in many low-income countries, other programs can be expanded while administrative capacity is being developed. These efforts should focus on existing programs that can be expanded quickly, possibly with some improvements in the effectiveness of targeting (for instance, school meals, public works, reductions in education and health user fees, subsidized mass urban transport, subsidies for water and electricity connection costs). Scaling up such programs should be done in conjunction with a more gradual approach to removing subsidies, for example, delaying fuel price increases for products (such as kerosene) that are used more by lower-income groups.

This approach has been used in a number of countries. Gabon, Ghana, Niger, Nigeria, and Mozambique expanded targeted social spending programs to protect lower-income households from fuel price increases. To alleviate the impact of its subsidy reform on the poor, Morocco expanded existing social programs (providing support to school-age children and helping the poor with medical expenses) and introduced new programs to support low-income widows and physically disabled individuals, in addition to providing support for the public transportation sector to mitigate the cost of higher fuel prices and limit fare increases. The Philippines maintained electricity subsidies for indigent families, provided college scholarships for low-income students, and subsidized loans to convert engines used in public transportation to less costly LPG (World Bank 2008). 
In the context of electricity reforms, Armenia, Brazil, Kenya, and Uganda kept their lower lifeline tariffs for electricity fixed and concentrated tariff increases on households with higher electricity consumption levels. Kenya subsidized connection costs in place of electricity price subsidies, which helped expand coverage to poor households and those in remote and rural areas. The rural electrification program helped increase the number of connections from 650,000 in 2003 to 2 million as of 2014 with a fund for connection fee payments financed by donors.

Even after removing current subsidies, many countries will be reluctant to make the big jump to complete price deregulation because of the concern that increasing and volatile international prices will adversely affect poor and middle-income households. As a result, although a number of countries have successfully undertaken subsidy reforms, in many cases subsidies have reemerged during periods of sharp or prolonged increases in international prices (for example, in Gabon, Ghana, Indonesia, and Jordan). For such countries, an attractive interim solution may be to adopt an automatic pricing mechanism that includes some formal built-in domestic price smoothing (Coady and others 2012). A number of countries (including Chile, Peru, and Mauritius, as well as countries in sub-Saharan Africa) already have adopted such mechanisms. This approach essentially shares international price volatility between domestic consumers and the budget. By allowing both price increases and decreases, but capping these changes, full pass-through of international price movements to domestic consumers is ensured over the medium term while these consumers are protected from sudden sharp increases and an escalating subsidy bill is avoided. Successful implementation of an automatic pricing mechanism can facilitate the transition to a liberalized pricing regime by getting the public accustomed to frequent changes in domestic energy prices. Also, by demonstrating the government's willingness to steer clear of subsidies and the associated market disruption, private sector confidence and investment in the energy sector-which is crucial for growth-can be renewed, paving the way for a more permanent solution through complete price deregulation. South Africa, the Philippines, and Turkey have successfully implemented automatic pricing mechanisms for fuel products, in the latter two cases during their transitions to liberalized fuel pricing. India liberalized gasoline and diesel prices in 2010 and 2014, respectively.

\section{Conclusions}

This paper revisits the issue of distribution of benefits from fuel subsidies in developing countries and updates and expands the results of a previous review by Arze del Granado, Coady, and Gillingham (2012). The results reinforce the previous finding that fuel subsidies are badly targeted, mainly benefiting higher-income groups, and are fiscally costly. But the withdrawal of subsidies can have a sizable impact on household welfare, including that of lower-income groups. The analysis finds that a $\$ 0.25$ per liter increase in fuel prices decreases household real incomes by, on average, 5.5 percent. Approximately half of this impact comes through the indirect effect on the prices of other goods and services consumed by households. 
The distribution of this welfare impact is approximately neutral, with the magnitude of the welfare loss being similar across income groups. However, reflecting the underlying unequal distribution of aggregate consumption, the richest 20 percent of households capture, on average, more than six times more in fuel subsidies than the poorest 20 percent, making universal fuel subsidies a very inefficient policy instrument for protecting poor households from fuel price increases. The benefits of gasoline subsidies are the most regressively distributed, with more than 83 percent of total benefits accruing to the richest 40 percent of households. Although the consumption of kerosene is more evenly distributed across income groups, a substantial amount of kerosene subsidies still goes to high-income households.

Given the adverse impact of subsidy reform on poor households, it is important that mitigating measures be implemented to protect these households. The paper discusses alternative strategies that can be used to achieve this end. Ideally, well-targeted cash transfers should be used to protect poor households. If such programs are not available, alternative approaches can be used, such as temporarily maintaining universal subsidies on commodities that are more important in the budgets of the poor; expanding existing safety net programs, possibly with some improvements in targeting; and increasing high-priority spending that benefit the poor, such as in health, education, and infrastructure. If countries are reluctant to fully pass through sharp increases in international fuel prices, they should consider adopting an automatic pricing mechanism with built-in price smoothing to protect households while ensuring full pass-through in the medium term. 
ANNeX 1. Supplementary TABles

Annex Table 1.1. Year of Report, Underlying Data, and Author Institution

\begin{tabular}{|c|c|c|c|c|}
\hline Country & Year of Report & $\begin{array}{c}\text { Year of } \\
\text { Household } \\
\text { Survey }\end{array}$ & $\begin{array}{l}\text { Year of } \\
\text { Input- } \\
\text { Output } \\
\text { Matrix }\end{array}$ & Author Institution \\
\hline \multicolumn{5}{|l|}{ Africa } \\
\hline Angola & 2014 & $2008 / 2009$ & 2014 & IMF \\
\hline Cameroon & 2007 & 2001 & 2001 & IMF \\
\hline Gabon & 2006 & 2005 & 2001 & IMF \\
\hline Central African Republic & 2006 & 2003 & 2001 & IMF \\
\hline Senegal & 2008 & 2005 & 2006 & IMF \\
\hline Ghana & 2005 & 1999 & 1993 & IMF \\
\hline Kenya & 2010 & 2006 & n.a. & World Bank \\
\hline Mali & 2006 & 2001 & 1998 & IMF \\
\hline Congo & 2008 & 2005 & 2005 & IMF \\
\hline Burkina Faso & 2008 & 2003 & 2007 & IMF \\
\hline Madagascar & 2007 & 2005 & n.a. & World Bank \\
\hline Madagascar & 2014 & 2010 & n.a. & IMF \\
\hline South Africa & 2014 & 2010 & 2010 & World Bank \\
\hline Uganda & 2010 & $2005 / 2006$ & n.a. & World Bank \\
\hline \multicolumn{5}{|l|}{ South and Central America } \\
\hline Bolivia & 2009 & 2007 & n.a. & IMF \\
\hline Peru & 2008 & 2007 & 1994 & IMF \\
\hline El Salvador & 2009 & 2005 & n.a. & IMF \\
\hline Honduras & 2006 & 2004 & 2004 & IMF \\
\hline Paraguay & 2011 & 2006 & 2006 & IMF \\
\hline \multicolumn{5}{|l|}{ Asia and Pacific } \\
\hline Bangladesh & 2006 & 2000 & 1993 & IMF \\
\hline Bangladesh & 2010 & 2005 & n.a. & World Bank \\
\hline Sri Lanka & 2006 & 1999 & 2001 & IMF \\
\hline Cambodia & 2010 & 2003/2004 & n.a. & World Bank \\
\hline India & 2010 & $2004 / 2005$ & n.a. & World Bank \\
\hline India & 2013 & 2010 & 2004 & IMF \\
\hline Indonesia & 2014 & 2012 & 2011 & $\begin{array}{c}\text { World Bank } \\
\text { IMF/Universiti Utara }\end{array}$ \\
\hline Malaysia & $2009 / 2013$ & 2005 & 2005 & Malaysia \\
\hline Pakistan & 2010 & $2004 / 2005$ & n.a. & World Bank \\
\hline Philippines & 2007 & 2003 & n.a. & IMF \\
\hline Thailand & 2010 & 2006 & n.a. & World Bank \\
\hline Vietnam & 2010 & 2006 & n.a. & World Bank \\
\hline \multicolumn{5}{|l|}{ Middle East and Central Asia } \\
\hline Jordan & 2005 & $2002 / 2003$ & 1998 & IMF \\
\hline Jordan & 2011 & $2008 / 2009$ & 2006 & IMF \\
\hline Lebanon & 2008 & 2004 & n.a. & IMF \\
\hline Sudan & 2012 & 2009 & n.a. & IMF \\
\hline Yemen & 2013 & 2006 & 2009 & IMF \\
\hline
\end{tabular}

Source: Authors' survey of the literature.

Note: n.a. $=$ not available. New studies in bold. 
Annex Table 1.2. Adjustment Factors by Country Study and Fuel Product

\begin{tabular}{|c|c|c|c|c|}
\hline & Gasoline & Kerosene & Diesel & LPG \\
\hline Angola & 0.32 & 0.69 & 0.48 & 0.54 \\
\hline Bangladesh & 0.54 & 0.86 & 0.86 & 0.70 \\
\hline Bangladesh & 0.22 & 0.33 & n.a & n.a \\
\hline Bolivia & 0.54 & 0.71 & 0.52 & 0.53 \\
\hline Burkina Faso & 0.29 & 0.57 & 0.40 & 0.35 \\
\hline Cambodia & 0.40 & 0.62 & 0.55 & 0.47 \\
\hline Cameroon & 0.40 & 0.92 & 0.48 & 0.44 \\
\hline Central African Republic & 0.24 & 0.45 & 0.27 & 0.26 \\
\hline Congo, Republic of & 0.30 & 0.49 & 0.45 & 0.37 \\
\hline El Salvador & 0.38 & n.a. & 0.41 & 0.39 \\
\hline Gabon & 0.29 & 0.59 & 0.38 & 0.34 \\
\hline Ghana & 0.96 & 1.42 & 1.02 & 0.99 \\
\hline Honduras & 0.36 & 0.53 & 0.47 & 0.42 \\
\hline India & 0.28 & 1.23 & 0.46 & 0.37 \\
\hline India & 0.20 & 0.92 & 0.29 & 0.03 \\
\hline Indonesia & 0.53 & 0.94 & n.a. & n.a. \\
\hline Jordan & 0.53 & 1.25 & 1.29 & 0.91 \\
\hline Jordan & 0.25 & 0.34 & 0.34 & 0.33 \\
\hline Kenya & 0.19 & 0.24 & n.a. & n.a. \\
\hline Lebanon & 0.35 & 0.67 & 0.72 & 0.54 \\
\hline Madagascar & 0.27 & 0.42 & 0.32 & 0.30 \\
\hline Madagascar & 0.19 & 0.23 & 0.15 & n.a \\
\hline Malaysia & 0.41 & 0.45 & n.a. & n.a. \\
\hline Mali & 0.36 & 0.59 & 0.58 & 0.47 \\
\hline Pakistan & 0.26 & 0.26 & n.a. & n.a. \\
\hline Paraguay & 0.17 & n.a. & 0.23 & n.a. \\
\hline Peru & 0.27 & 0.27 & 0.27 & 0.27 \\
\hline Philippines & 0.66 & 0.81 & 0.82 & 1.04 \\
\hline Senegal & 0.25 & 0.28 & 0.28 & 0.27 \\
\hline South Africa & 0.24 & 0.38 & 0.27 & n.a. \\
\hline Sri Lanka & 0.33 & 0.95 & 0.88 & 0.61 \\
\hline Sudan & 0.34 & 0.48 & 0.51 & 0.86 \\
\hline Thailand & 0.18 & 0.22 & n.a. & n.a. \\
\hline Uganda & 0.16 & 0.21 & n.a. & n.a. \\
\hline Vietnam & 0.22 & 0.24 & n.a. & n.a. \\
\hline Yemen & 0.43 & 0.54 & n.a. & 0.54 \\
\hline
\end{tabular}

Source: Authors' calculations based on results from reviewed studies.

Note: $\mathrm{LPG}=$ liquefied petroleum gas; n.a. = not available. For countries with more than one study available, results are reported in chronological order; please refer to Table 1.1 for year of report/underlying data. 


\section{Annex Table 1.3. Direct and Indirect Welfare Impacts of Fuel Price Increases}

\begin{tabular}{|c|c|c|c|c|c|c|c|}
\hline & \multicolumn{4}{|c|}{ Direct by Product } & \multirow[t]{2}{*}{ Direct } & \multirow[t]{2}{*}{ Indirect } & \multirow[t]{2}{*}{ Total } \\
\hline & Gasoline & Kerosene & LPG & Electricity & & & \\
\hline Africa (average) & 0.3 & 0.9 & 0.2 & 0.4 & 1.7 & 3.2 & 5.0 \\
\hline Cameroon & 0.2 & 1.4 & 0.1 & 0.5 & 2.3 & 1.3 & 3.6 \\
\hline Gabon & 0.2 & 0.3 & 0.5 & 1.2 & 2.2 & 3.5 & 5.6 \\
\hline Central African Republic & 0.0 & 0.6 & 0.0 & 0.0 & 0.7 & 2.8 & 3.5 \\
\hline Senegal & 0.1 & 0.3 & 0.3 & 0.4 & 1.0 & 1.1 & 2.1 \\
\hline Ghana & 0.6 & 5.0 & 0.1 & n.a. & 5.6 & 11.7 & 17.3 \\
\hline Mali & 0.4 & 0.9 & n.a. & 0.3 & 1.5 & 1.4 & 2.9 \\
\hline Congo, Republic of & 0.0 & 0.9 & 0.0 & 0.3 & 1.3 & 7.7 & 9.0 \\
\hline Burkina Faso & 0.5 & 0.6 & 0.0 & 0.2 & 1.3 & 0.7 & 2.0 \\
\hline Madagascar & 0.0 & 0.8 & n.a. & 0.2 & 1.0 & n.a. & 1.0 \\
\hline Angola & 1.1 & 0.6 & 0.2 & n.a. & 1.9 & 2.2 & 4.2 \\
\hline Kenya & 0.0 & 0.5 & n.a. & n.a. & 0.5 & n.a. & 0.5 \\
\hline Madagascar & 0.1 & 0.3 & n.a. & n.a. & 0.4 & n.a. & 0.4 \\
\hline South Africa & 0.8 & 0.0 & n.a. & n.a. & 0.8 & 0.1 & 0.9 \\
\hline Uganda & 0.0 & 0.3 & n.a. & n.a. & 0.4 & n.a. & 0.4 \\
\hline South and Central America (average) & 0.2 & 0.2 & 0.3 & 0.8 & 1.4 & 2.0 & 3.5 \\
\hline Bolivia & 0.3 & n.a. & 0.5 & n.a. & 0.7 & 2.9 & 3.6 \\
\hline Peru & 0.1 & 0.1 & 0.3 & 0.5 & 0.9 & 0.7 & 1.7 \\
\hline El Salvador & 0.2 & 0.1 & 0.3 & 1.1 & 1.7 & n.a. & 1.7 \\
\hline Honduras & 0.1 & 0.4 & 0.2 & 0.7 & 1.4 & 3.5 & 5.0 \\
\hline Paraguay & 0.2 & n.a. & n.a. & n.a. & 0.2 & 1.1 & 1.3 \\
\hline Asia and Pacific (average) & 0.6 & 1.0 & 0.4 & 1.3 & 3.2 & 2.7 & 5.9 \\
\hline Bangladesh & 0.1 & 0.9 & 0.1 & 0.7 & 1.7 & 1.5 & 3.2 \\
\hline Sri Lanka & 0.2 & 1.0 & 0.3 & 1.1 & 2.7 & 2.6 & 5.3 \\
\hline Cambodia & n.a. & 0.3 & 0.4 & 1.5 & 2.2 & n.a. & 2.2 \\
\hline India & 0.2 & 1.8 & 0.4 & 1.1 & 3.6 & n.a. & 3.6 \\
\hline Indonesia & 0.7 & 4.1 & 0.2 & 3.8 & 8.8 & n.a. & 8.8 \\
\hline Bangladesh & 0.0 & 0.3 & n.a. & n.a. & 0.3 & n.a. & 0.3 \\
\hline India & 0.1 & 1.0 & 0.0 & n.a. & 1.1 & 1.4 & 2.5 \\
\hline Malaysia & 2.7 & n.a. & n.a. & 0.3 & 3.0 & 5.5 & 8.5 \\
\hline Pakistan & 0.3 & 0.1 & n.a. & n.a. & 0.3 & n.a. & 0.3 \\
\hline Philippines & 0.1 & 0.3 & 1.0 & 0.4 & 1.9 & n.a. & 1.9 \\
\hline Thailand & 1.1 & n.a. & n.a. & n.a. & 1.1 & n.a. & 1.1 \\
\hline Vietnam & 0.7 & 0.1 & n.a. & n.a. & 0.8 & n.a. & 0.8 \\
\hline Middle East and Central Asia (average) & 0.9 & 0.4 & 0.9 & 1.4 & 3.5 & 3.4 & 7.0 \\
\hline Jordan & 0.9 & 0.7 & 1.1 & 3.0 & 5.7 & 6.3 & 12.1 \\
\hline Lebanon & 1.9 & n.a. & 0.8 & 2.4 & 5.1 & 2.0 & 7.1 \\
\hline Jordan & 1.1 & 0.2 & 0.7 & 0.2 & 2.2 & 3.6 & 5.8 \\
\hline Sudan & 0.1 & 0.1 & n.a. & 0.1 & 0.3 & 2.4 & 2.8 \\
\hline Yemen & 0.3 & 0.4 & 0.9 & n.a. & 1.7 & 2.7 & 4.4 \\
\hline All regions (average) & 0.4 & 0.8 & 0.4 & 0.9 & 2.5 & 3.0 & 5.5 \\
\hline Only regions with indirect effect & 0.5 & 0.8 & 0.3 & 0.7 & 2.4 & 3.0 & 5.4 \\
\hline
\end{tabular}

Source: Authors' calculations based on results from reviewed studies.

Note: $L P G=$ liquefied petroleum gas; n.a. $=$ not available. 
Annex Table 1.4. Composition of Indirect Impact

(Percent of household total consumption)

\begin{tabular}{|c|c|c|c|c|c|c|c|c|c|}
\hline Region/country & & idget Share & & & Price Effect & & & rect Impact & \\
\hline & Food & Transport & Others $^{1 /}$ & Food & Transport & Others $^{1 /}$ & Food & Transport & Others ${ }^{1 /}$ \\
\hline Bangladesh & 65.7 & 2.7 & 29.9 & 0.02 & 0.07 & 0.01 & 1.00 & 0.19 & 0.31 \\
\hline Burkina Faso & 57.0 & 0.7 & 40.9 & 0.01 & 0.07 & 0.01 & 0.31 & 0.05 & 0.30 \\
\hline Cameroon & 44.5 & 5.9 & 47.3 & 0.01 & 0.06 & 0.01 & 0.35 & 0.34 & 0.63 \\
\hline $\begin{array}{l}\text { Central African } \\
\text { Republic }\end{array}$ & 47.1 & 0.9 & 51.3 & 0.02 & 0.14 & 0.03 & 1.14 & 0.13 & 1.57 \\
\hline Congo, Republic of & 41.4 & 10.9 & 46.4 & 0.02 & 0.09 & 0.12 & 0.98 & 1.02 & 5.71 \\
\hline Gabon & 48.8 & 3.5 & 45.5 & 0.04 & 0.03 & 0.03 & 1.83 & 0.11 & 1.48 \\
\hline Ghana & 45.2 & 3.2 & 46.0 & 0.12 & 0.47 & 0.10 & 5.25 & 1.50 & 4.93 \\
\hline Jordan ${ }^{2 l}$ & 41.0 & 0.0 & 53.3 & 0.06 & N.A. & 0.06 & 2.58 & N.A. & 3.77 \\
\hline Malaysia & 20.7 & 15.9 & 53.5 & 0.06 & 0.09 & 0.09 & 1.29 & 1.45 & 2.74 \\
\hline Mali & 45.6 & 0.9 & 52.0 & 0.01 & 0.12 & 0.01 & 0.59 & 0.11 & 0.72 \\
\hline Paraguay & 40.8 & 8.6 & 48.5 & 0.01 & 0.05 & 0.00 & 0.38 & 0.44 & 0.25 \\
\hline Peru & 51.2 & 1.8 & 46.2 & 0.01 & 0.03 & 0.01 & 0.42 & 0.05 & 0.27 \\
\hline Senegal & 49.3 & 3.0 & 46.7 & 0.00 & 0.01 & 0.02 & 0.25 & 0.02 & 0.81 \\
\hline Sri Lanka & 56.1 & 2.5 & 38.7 & 0.03 & 0.10 & 0.02 & 1.80 & 0.25 & 0.58 \\
\hline Sudan & 63.0 & 4.9 & 29.7 & 0.03 & 0.10 & N.A. & 1.94 & 0.50 & N.A. \\
\hline Yemen & 69.5 & 0.9 & 26.0 & 0.03 & 0.03 & 0.02 & 2.20 & 0.03 & 0.51 \\
\hline $\begin{array}{l}\text { All countries } \\
\text { (average) }\end{array}$ & 49.2 & 4.1 & 43.9 & 0.03 & 0.10 & 0.04 & 1.4 & 0.4 & 1.6 \\
\hline Share in total impact & $\ldots$ & $\ldots$ & & 18.43 & 59.37 & 22.20 & 40 & 12 & 48 \\
\hline
\end{tabular}

Note: [N.A.] indicates information not available in the country study.

${ }^{1}$ Category "others" excludes fuel products directly consumed by households for cooking, lighting, and transport. Hence, budget shares do not add to 100, but to 100 minus household's share of consumption in fuel products. The price effect is the proportionate increase in prices resulting from a $\$ 0.25$ per liter increase in fuel prices. The indirect impact is the product of budget shares and the price impact.

2Jordan's report did not disaggregate transport from other nonfood expenditures. 
Annex Table 1.5 Distribution of Impacts by Region

\begin{tabular}{|c|c|c|c|c|c|c|}
\hline & & umpt & Quin & & & \\
\hline & Bottom & 2 & 3 & 4 & Top & $\begin{array}{c}\text { All } \\
\text { households }\end{array}$ \\
\hline Africa & & & & & & \\
\hline Total Impact & 4.7 & 4.8 & 4.8 & 5.0 & 5.3 & 5.0 \\
\hline Total Direct Impact & 1.7 & 1.6 & 1.6 & 1.6 & 1.9 & 1.7 \\
\hline Gasoline & 0.1 & 0.1 & 0.2 & 0.3 & 0.5 & 0.3 \\
\hline Kerosene & 1.3 & 1.1 & 0.9 & 0.7 & 0.5 & 0.9 \\
\hline LPG & 0.1 & 0.2 & 0.2 & 0.3 & 0.3 & 0.2 \\
\hline Electricity & 0.2 & 0.3 & 0.3 & 0.4 & 0.6 & 0.4 \\
\hline Indirect Impact & 3.0 & 3.1 & 3.2 & 3.4 & 3.4 & 3.2 \\
\hline South \& Central Ameri & & & & & & \\
\hline Total Impact & 3.8 & 3.7 & 3.9 & 4.1 & 3.9 & 3.5 \\
\hline Total Direct Impact & 1.1 & 1.3 & 1.5 & 1.7 & 1.6 & 1.4 \\
\hline Gasoline & 0.0 & 0.1 & 0.1 & 0.3 & 0.4 & 0.2 \\
\hline Kerosene & 0.4 & 0.3 & 0.1 & 0.1 & 0.0 & 0.2 \\
\hline LPG & 0.2 & 0.3 & 0.4 & 0.4 & 0.3 & 0.3 \\
\hline Electricity & 0.4 & 0.6 & 0.8 & 0.9 & 0.9 & 0.8 \\
\hline Indirect Impact & 2.7 & 2.4 & 2.4 & 2.4 & 2.3 & 2.0 \\
\hline Asia and Pacific & & & & & & \\
\hline Total Impact & 4.1 & 4.7 & 5.0 & 5.3 & 5.5 & 5.9 \\
\hline Total Direct Impact & 2.3 & 2.7 & 3.0 & 3.3 & 3.6 & 3.2 \\
\hline Gasoline & 0.3 & 0.4 & 0.5 & 0.6 & 0.8 & 0.6 \\
\hline Kerosene & 1.3 & 1.2 & 1.1 & 1.0 & 0.6 & 1.0 \\
\hline LPG & 0.0 & 0.2 & 0.3 & 0.4 & 0.6 & 0.4 \\
\hline Electricity & 0.7 & 0.9 & 1.1 & 1.3 & 1.6 & 1.3 \\
\hline Indirect Impact & 1.8 & 2.0 & 2.0 & 2.0 & 1.9 & 2.7 \\
\hline Middle East \& Central A & & & & & & \\
\hline Total Impact & 8.7 & 7.7 & 7.5 & 7.1 & 6.7 & 7.0 \\
\hline Total Direct Impact & 3.9 & 3.6 & 3.6 & 3.4 & 3.1 & 3.5 \\
\hline Gasoline & 0.4 & 0.7 & 1.0 & 1.1 & 1.2 & 0.9 \\
\hline Kerosene & 0.6 & 0.4 & 0.4 & 0.3 & 0.2 & 0.4 \\
\hline LPG & 1.2 & 1.0 & 0.8 & 0.7 & 0.5 & 0.9 \\
\hline Electricity & 1.7 & 1.4 & 1.4 & 1.3 & 1.2 & 1.4 \\
\hline Indirect Impact & 4.8 & 4.1 & 3.9 & 3.7 & 3.6 & 3.4 \\
\hline All Regions & & & & & & \\
\hline Total Impact & 5.4 & 5.4 & 5.5 & 5.6 & 5.7 & 5.5 \\
\hline Direct Impact & 2.3 & 2.3 & 2.4 & 2.5 & 2.6 & 2.5 \\
\hline Gasoline & 0.2 & 0.3 & 0.4 & 0.5 & 0.7 & 0.4 \\
\hline Kerosene & 1.1 & 1.0 & 0.8 & 0.7 & 0.4 & 0.8 \\
\hline LPG & 0.3 & 0.3 & 0.4 & 0.4 & 0.4 & 0.4 \\
\hline Electricity & 0.7 & 0.7 & 0.8 & 0.9 & 1.1 & 0.9 \\
\hline Indirect Impact & 3.1 & 3.0 & 3.1 & 3.1 & 3.1 & 3.0 \\
\hline
\end{tabular}

*Indirect impact is not available by quintile for all countries. The reported values are medians of available observations. 
Annex Table 1.6 Distribution of Subsidy Benefits by Consumption Group

\begin{tabular}{|c|c|c|c|c|c|c|}
\hline & \multicolumn{5}{|c|}{ Consumption Quintiles } & \multirow{2}{*}{$\begin{array}{c}\text { All } \\
\text { households }\end{array}$} \\
\hline & Bottom & 2 & 3 & 4 & Top & \\
\hline \multicolumn{7}{|l|}{ Africa } \\
\hline Total Impact & 7.1 & 10.7 & 14.9 & 20.8 & 46.5 & 100 \\
\hline Total Direct Impact & 7.7 & 10.6 & 14.2 & 19.8 & 47.6 & 100 \\
\hline Gasoline & 1.5 & 2.9 & 6.3 & 16.2 & 73.1 & 100 \\
\hline Kerosene & 14.0 & 21.2 & 19.2 & 20.4 & 25.2 & 100 \\
\hline LPG & 2.7 & 6.5 & 11.7 & 22.4 & 56.6 & 100 \\
\hline Indirect Impact & 6.2 & 10.1 & 14.8 & 21.5 & 47.4 & 100 \\
\hline \multicolumn{7}{|l|}{ South \& Central America } \\
\hline Total Impact & 6.0 & 10.7 & 16.3 & 23.2 & 43.8 & 100 \\
\hline Total Direct Impact & 5.2 & 9.9 & 15.3 & 22.0 & 47.4 & 100 \\
\hline Gasoline & 3.0 & 6.3 & 11.5 & 23.2 & 56.0 & 100 \\
\hline Kerosene & 29.2 & 25.2 & 20.5 & 16.9 & 8.1 & 100 \\
\hline LPG & 3.4 & 8.7 & 16.0 & 24.2 & 47.8 & 100 \\
\hline Indirect Impact & 7.5 & 12.6 & 18.1 & 23.7 & 38.2 & 100 \\
\hline \multicolumn{7}{|l|}{ Asia and Pacific } \\
\hline Total Impact & 6.3 & 10.4 & 14.9 & 22.4 & 46.0 & 100 \\
\hline Total Direct Impact & 6.2 & 10.3 & 14.6 & 21.7 & 47.3 & 100 \\
\hline Gasoline & 2.5 & 5.2 & 9.0 & 17.0 & 66.4 & 100 \\
\hline Kerosene & 17.1 & 20.6 & 22.0 & 22.2 & 18.1 & 100 \\
\hline LPG & 0.3 & 2.9 & 8.0 & 18.6 & 70.2 & 100 \\
\hline Indirect Impact & 10.0 & 13.6 & 17.0 & 22.4 & 37.2 & 100 \\
\hline \multicolumn{7}{|c|}{ Middle East \& Central Asia } \\
\hline Total Impact & 8.6 & 12.8 & 17.2 & 22.4 & 39.0 & 100 \\
\hline Total Direct Impact & 9.5 & 13.4 & 16.9 & 21.7 & 38.5 & 100 \\
\hline Gasoline & 4.3 & 8.8 & 13.5 & 20.4 & 53.0 & 100 \\
\hline Kerosene & 18.2 & 20.5 & 22.0 & 21.9 & 17.5 & 100 \\
\hline LPG & 11.9 & 15.8 & 19.3 & 22.7 & 30.3 & 100 \\
\hline Indirect Impact & 8.5 & 12.7 & 16.9 & 22.1 & 39.7 & 100 \\
\hline \multicolumn{7}{|l|}{ All Regions } \\
\hline Total Impact & 7.0 & 11.0 & 15.6 & 21.9 & 45.0 & 100 \\
\hline Direct Impact & 7.1 & 10.8 & 14.9 & 20.9 & 46.2 & 100 \\
\hline Gasoline & 2.4 & 5.0 & 9.0 & 18.2 & 65.0 & 100 \\
\hline Kerosene & 17.5 & 21.4 & 20.6 & 20.7 & 19.7 & 100 \\
\hline LPG & 4.4 & 8.3 & 13.5 & 22.0 & 51.9 & 100 \\
\hline Indirect Impact & 7.2 & 11.3 & 16.0 & 22.1 & 43.3 & 100 \\
\hline
\end{tabular}

*Indirect impact is not available by quintile for all countries. 


\section{REFERENCES}

Arze del Granado, F. J., D. Coady, and R. Gillingham. 2012. "The Unequal Benefits of Fuel

Subsidies: A Review of Evidence for Developing Countries." World Development 40 (11): 2234-48.

Clements, B., D. Coady, S. Fabrizio, S. Gupta, T. Alleyne, and C. Sdralevich, eds. 2013. Energy Subsidy Reform: Lessons and Implications. (Washington: International Monetary Fund).

http://www.elibrary.imf.org/page/energysubsidylessons.

Coady, D., J. Arze del Granado, L. Eyraud, H. Jin, V. Thakoor, A. Tuladhar, and L. Nemeth. 2012.

"Automatic Fuel Pricing Mechanisms with Price Smoothing: Design, Implementation, and Fiscal Implications." Technical Notes and Manuals No. 12/03, (Washington: International Monetary Fund). http://www.imf.org/external/pubs/ ft/tnm/2012/tnm1203.pdf.

Coady, D., and D. Newhouse. 2006. "Evaluating the Distribution of the Real Income Effects of Increases in Petroleum Product Prices in Ghana." In Analyzing the Distributional Impacts of Reforms: Operational Experience in Implementing Poverty and Social Impact Analysis, edited by A. Coudouel, A. Dani, and S. Paternostro. (Washington: World Bank).

Fiszbein, A., and N. Schady. 2009. Conditional Cash Transfers: Reducing Present and Future Poverty. (Washington: World Bank).

Garcia, M., and C. Moore. 2012. The Cash Dividend: The Rise of Cash Transfer Programs in SubSaharan Africa. (Washington: World Bank).

Grosh, M. E., C. del Ninno, E. Tesliuc, and A. Ouerghi. 2008. For Protection and Promotion: The Design and Implementation of Effective Safety Nets. (Washington: World Bank).

Monchuk, V. 2014. Reducing Poverty and Investing in People: The New Role of Safety Nets in Africa. (Washington: World Bank).

Newbery, D., and N. Stern, eds. 1987. The Theory of Taxation in Developing Countries. (Washington: Oxford University Press for World Bank).

World Bank. 2008. "Philippines Quarterly Update." (Washington). http://documents.worldbank.org/curated/ en/2008/11/11962976/philippines-quarterly-update. 